KRITIKE E VOLUME ONE NUMBER ONE (JUNE 2007) 71-85

Article

\title{
Against Alienation: Karol Wojtyla's Theory of Participation
}

Dean Edward A. Mejos

\section{Introduction}

$\mathrm{M}$

an's thought is greatly affected by his experiences in life. A person is a subject who lives alongside different objects (some of these objects are also subjects like him) and he grows and develops as he interacts with these objects that are around him. Man's fulfillment is something which requires an active interaction with the world because it is through his interaction with the world that he is called upon to perform specific actions which inevitably form him as a person.

Karol Wojtyla's works focus on man as a personal being - who exists and acts in a certain way towards his proper end. As a philosopher, his thoughts can be traced mainly to St. Thomas Aquinas and Max Scheler. What stands out is a meeting of metaphysics and phenomenology - objectivity and subjectivity. Wojtyla's thought does not try to favor one over another but, rather, he bridges the objective and the subjective in his study of the person. The return to the person is also reflective of his pastoral work throughout his papacy. His encyclicals Centisimus Annus, Fides et Ratio, Laborem Exercens, Redemptor Hominis, and Veritatis Splendor reflect his personalist philosophy.

One of the problems that Karol Wojtyla's thought addressed is the problem of Alienation. Sourced from the Marxist paradigm, alienation refers to the separation of things that naturally belong together. In ordinary terms, alienation means being separated from something that one rightfully has ownership to. For example: a person may be alienated from his private property by virtue of some law or some event. For Wojtyla, alienation is a problem and a hindrance to a person's fulfillment through his actions. Alienation is not a threat to man as a human being but is a threat to him as a person.

His answer to the problem of alienation is his theory of Participation described as a property of the person as well as an ability to share in the humanity of others. This affirms the fact that man exists and acts together with others. He is a member of a community in the form of an "I-you" and a "we" relationship. It consequently means then, that the constant challenge to seek and to find answers to the issues regarding one's personhood and his world is a task that is common to each person that can also be taken as a task of the entire community. 


\section{AGAINST ALIENATION}

\section{The Person and Community}

Karol Wojtyla's analysis of the person begins with the starting point of knowledge - experience. The richness of the human person cannot be encapsulated in words but in what he calls The Experience of Man. The starting point of the analysis of the person is the experience of existing and acting together with others. The object of the experience of man is himself, a subject but at the same time, he also experiences others as subjects. In the experience of man, he is both the subject and object of experience. The experience of man involves an "inner" and "outer" aspect. ${ }^{1}$ The inner aspect refers to the experience of the person within and hence, this experience is unique to the person and non-transferable. The outer aspect refers to the other persons who are the objects of experience.

Traditionally (from Boethius), the person is defined as "an individual substance of rational nature." Wojtyla does not outright reject this definition but warns of its tendency to go into a cosmological understanding of the human person. The danger of a cosmological understanding of the human person is that he is reduced to simply being a part of the world. Man is objectified - he becomes an object among objects. For him, what really separates a person from the rest of the creatures in the world is his spirituality. Wojtyla says:

A person differs from a thing in structure and in degree of perfection. To the structure of the person belongs an 'interior', in which we find the elements of spiritual life, and it is this that compels us to acknowledge the spiritual nature of the human soul, and the peculiar perfectibility of the human person. This determines the value of the person. A person must not be put on the same level as a thing (or for that matter as an individual animal): the person possesses spiritual perfectibility, and is by way of being an (embodied) spirit, not merely a 'body' magnificently endowed with life. Between the psyche of an animal and the spirituality of a man, there is an enormous distance, an uncrossable gulf. ${ }^{2}$

Wojtyla describes this experience as "man-acts" or that "I-act" when a person performs an action. When a person acts, he acts deliberately because he has dominion over himself and his actions. In acting, the person experiences the "moment of efficacy." This is to have the experience of being

${ }^{1}$ Melchor Montalbo, "Karol Wojtyla's Philosophy of the Person," in The Thomasian Philosopher, vol. 26 (2005), 11.

${ }^{2}$ Karol Wojtyla, Love and Responsibility (San Francisco: Ignatius Press, 1993), 121. 
the actor. ${ }^{3}$ This means the experience of oneself as the source and the cause of the act.

There are also other special characteristics of the actus humanus: an action has two dimensions: it has a reflective and a reflexive character. Reflective in the sense that it is a way by which a person is reflected by his actions. In a certain way of saying, his actions reveal himself to himself as well as to those around him.

For us action reveals the person, and we look at the person through his action. For it lies in the nature of the correlation inherent in experience, in the very nature of man's acting, that action constitutes the specific moment whereby the person is revealed. Action gives us the best insight into the inherent essence of the person and allows us to understand the person most fully. ${ }^{4}$

As much as human actions reflect the person, human actions also go back to him in the sense that these human actions always have a moral and existential modality in them. Human actions have an intrinsic quality which can be positively charged or negative depending on the nature of the act itself. One does not only have the moment of efficacy but one also experiences the moral and existential quality of one's actions. Special attention is given here because moral values not only determine the inner quality of human actions, but they also never enter into a dynamic imprint sequence of actions without leaving an imprint whereby man as a person, owing to his actions that may be good or evil, himself becomes either good or evil..$^{5}$ A person is a project - he enacts his existence in his self-determining actions. ${ }^{6}$

Human actions are a very important element in the understanding of the human person. Through which, the truth about the person is revealed and as well as his means of reaching his fulfillment. Human action is a rich source from which the truth about the person is revealed. One becomes conscious of himself in his acting and it also gives him a deeper view of himself and his actions. This allows him to see that these actions come from within him. To fully appreciate this, one must not only be able to experience himself as the agent and the origin of the act, but he must also experience the value of the act. One must also be able to experience the fulfillment of the act - not only in the sense that he can see the act reach its terminus but he must also be able to experience the act reaching its telos. Fulfilling oneself is not identical with fulfilling an action, but depends on the moral value of that action. ${ }^{7}$ A person

\footnotetext{
${ }^{3}$ Karol Wojtyla, The Acting Person, trans. by Andrej Potocki, (Dordrecht: D. Reidel Publishing Company, 1979), 66.

${ }^{4}$ Ibid., 11.

${ }^{5}$ Ibid., 13.

${ }^{6}$ Montalbo, op cit., 21.

7 Karol Wojtyla, "The Person: Subject and Community," in Person and Community Selected Essays (New York: Peter Lang, 1993), 235.
} 


\section{AGAINST ALIENATION}

fulfills himself not by the fact that he fulfills (finishes) an action but by the fact that he becomes good when an act is morally good. It is only in this two-fold experience of fulfillment can a person truly appreciates the value and worth of himself and his actions.

\section{The Acting Person as an Intersubjective Person}

The starting point which is the experience of man in terms of gaining a deeper insight into the human person is never in isolation or in opposition to others. ${ }^{8}$ A person also experiences himself existing together with others. A community refers to a community of persons, a group of "I's" co-existing and co-acting with one another. The experience of man also includes the experience of others. The "I-You" relationship affirms the subjectivity of both parties.

The growth of a person cannot happen in isolation from others. By forming communities and reaching out to others, he affirms himself even more. These are relationships in which human beings mutually reveal themselves to one another in their personal human subjectivity and in all that goes to make up this subjectivity.9 The "I-Thou" relationship is a mutual relation of two subjects which takes on meaning but at the same time also becomes an authentic subjective community. In a truly proper interpersonal community, persons reveal themselves and relate to one another as acting persons. They reveal themselves in their deepest structure of self-possession and self-governance. They also reveal themselves to one another striving for fulfillment, which, culminating in acts of conscience, testifies to the transcendence proper to the human being as a person. ${ }^{10}$ The interpersonal community is a community of persons who are responsible for themselves as well as for others. Such responsibility is a reflection of conscience and of the transcendence that for both the I and the thou constitutes the path to selffulfillment, and at the same time, characterizes the proper, authentically personal dimension of the community. ${ }^{11}$

From an "I-You" relationship, the person begins to enter into a "We" relationship. From the interpersonal dimension of the community, it enters into a social dimension. The social dimension of a community is expressed in the pronoun "we." The "I-You" relationship which describes persons standing apart from each other now becomes a relationship wherein the parties involved are united as a group. The "we" relation does not dissolve the existence of individual persons but binds the multiplicity of "I's" toward a common end. Wojtyla explains:

A we is many human beings, many subjects, who in some way exist and act together. Acting "together" (i.e., "in

\footnotetext{
8 Ibid., 221.

${ }^{9}$ Ibid., 245.

${ }^{10}$ Ibid.

${ }^{11}$ Ibid., 246.
} 
common") does not mean engaging in a number of activities that somehow go along side by side. Rather it means that these activities, along with the existence of those many I's are related to a single value, which therefore deserves to be called the common good. ${ }^{12}$

People who engage in a we relationship experience themselves existing and acting together with others but they experience this in a whole new dimension. Persons do not lose themselves in the we relation but they experience a change in their direction - something which is determined by the common good. They not only experience their co-existence and co-acting but also experience their unity. Apart from the personal subjectivity, the community of persons in the we relationship also gains its own subjectivity. The formation of the we relationship is not something which simply happens but comes as a result of self-determined actions of the person realizing that he is not alone in his pursuit of fulfillment. It comes to be through a recognition of the common humanity shared by persons. The we relationship not only allows a person to form a new kind of relationship with others but he is also able to experience his humanity as well as the humanity of others more fully.

\section{The Evil of Alienation}

Alienation ordinarily refers to the act of being dissociated from something that rightfully belongs to oneself. Wojtyla says:

The concept of alienation, which was introduced into philosophy in the $19^{\text {th }}$ century and adopted by Marx, seems to be making a great comeback today . . .. According to Marx's philosophy, human beings are alienated by their products: their economic and political systems, their property, and their work. ${ }^{13}$

For Wojtyla, alienation negates the person as a subject. ${ }^{14}$ Alienation hinders the person to experience a person as another "I." Alienation signifies that man is deprived of the personalistic value of his action. ${ }^{15}$ The other is not recognized as a neighbor but is recognized as a stranger or even an enemy. ${ }^{16}$ Alienation devastates the I-other relationship, weakens the ability to experience another human being as another $I$, and inhibits the possibility of friendship and the spontaneous powers of community. ${ }^{17}$ Alienation is essentially a personalistic problem. It contributes to or creates an occasion for depriving people in some

12 Ibid., 247.

${ }^{13}$ Ibid., 205.

${ }^{14}$ Rolyn B. Francisco, Karol Wojtyla's Theory of Participation (Makati: St. Paul's, 1995), 76.

${ }_{15}$ Peter Simpson, On Karol Wojtyla (Australia: Wadsworth, 2001), 45.

${ }^{16}$ Loc cit.

${ }^{17}$ Wojtyla, Person and Community Selected Essays, 206. 


\section{AGAINST ALIENATION}

respect the possibility of fulfilling themselves in community, either in the social community of a we or in the interpersonal community. ${ }^{18}$ Alienation treats the person as an outsider - someone who is not a member of the community. Alienation denies the person of his right and ability to associate himself with others to form an interpersonal community. The real threat of alienation is not so much that it "dehumanizes" the human being as an individual member of the species but because it threatens the person as a subject. The reduction or the non-affirmation of the person as a personal subject, capable of fulfilling and transcending himself is one of the greatest dangers posed by alienation.

A society that fosters alienation eventually leads persons to being in isolation from one another. Persons not only miss out on the wealth of experience gained by entering into an interpersonal community but also deny themselves the property to participate in the achievement and the benefits of the common good. Alienation limits the person in his search for selffulfillment because it disallows him from transcending himself to reach out to others and ultimately to reach out to himself. In alienation, one cannot have the experience of entering into a we relationship. Alienation also denies the person of the experience of the value and fulfillment of his actions. The origin and cause of alienation cannot be singled out to point only to one factor because there could be many things involved in the process of alienating persons from other persons and from their actions. Actions must be performed not because only then can it have an ethical value - and can that value be assigned to it - but also because the person has the basic and "natural" (i.e., issuing from the fact that he is a person) right to perform actions and to be fulfilled in them. ${ }^{19}$ Alienation can be caused by the person to himself or it can be done to him by society or it could be a combination of both. In Wojtyla's analysis of alienation, he presents two prevalent systems that foster it:

Individualism is a system that puts high emphasis on the individuality of persons. Individualism arises from a lack in the person. ${ }^{20}$ Wojtyla says that individualism sees in the individual the supreme and fundamental good, to which all interests of the community or the society have to be subordinated. ${ }^{21}$ Individualism isolates the person from others as an individual who concentrates on himself and on his own goods. ${ }^{22}$ As priority is given to individual goods, individualism also considers community goods as threat to the individual. Other people are sources of limitation and ultimately present conflict. In individualism, what exist are merely individuals who are acting on their own apart from others. In this setup, there is no sense of fulfillment to be found in forming a community where people can experience themselves acting together with others. People are described to be egoistic because their only concern is their own good. The community is not there to help him out

\footnotetext{
18 Ibid., 255-256.

19 Wojtyla, The Acting Person, 272.

${ }^{20}$ Simpson, op cit., 39.

${ }^{21}$ Wojtyla, The Acting Person 273.

22 Ibid., 273-274.
} 
but rather, it is only there to get in the way of what he wants. The individualist mindset has a narrow and short perspective on the world and on oneself. Individualism isolates the person from the community and conceives him solely as an individual who concentrates on the pursuit of his own individual good. Primary individual goods include self-preservation and self-defense from others. Wojtyla adds:

From the point of view of individualism, to act "together with others," just as to exist "together with others," is a necessity that the individual must submit to, a necessity that corresponds to none of his very own features or positive properties; neither does the acting and existing with others serve or develop any individual's positive and essential constituents. ${ }^{23}$

There is no good to be found in working together with others except for one's personal gain. In individualism, community activities may be accomplished but are merely forced or imposed on them by authorities. The individual accepts these as "necessary evils" in order for him to further pursue his individual goals. Although Wojtyla does not make any mention of any specific nation or state which practices such, the phenomenon of individualism is highly visible in different forms of communities.

The opposite of individualism is Totalism. This system is a reversal of individualism in the sense that the individual is seen as a threat to the good of the community. The dominant trait of totalism may be characterized as the need to find protection from the individual, who is seen as the chief enemy of the society and the common good. ${ }^{24}$ As the opposite of individualism, it works under the assumption that all the goods that the individual is seeking are only individual goods and thus are understood as an obstacle to the common good. The good of the individual must be put aside for the sake of the common good. The common good can only be achieved if the individual is limited. This means that the common good is only possible on the basis of the elimination of the individual who is seeking only his individual interests or at least by limiting and restricting the individual. This includes a considerable amount of coercion which prevents the individual from choosing and pursuing his own goods. Individual goods are always incompatible with the common good. In totalism, there is also a tendency that persons may be coerced to contribute to the achievement of the common good. It is not surprising that a state or even a small community running on the lines of totalism will end up committing violations of fundamental rights of human beings as persons. Persons are not allowed to pursue their own individual growth under the assumption that it will not bring any contribution to the social group.

$$
\begin{aligned}
& { }^{23} \text { Ibid., } 274 . \\
& { }^{24} \text { Ibid. }
\end{aligned}
$$




\section{AGAINST ALIENATION}

As much as these two systems are opposed to one another, their weakness is found in their false understanding of the human person. Both systems alienate the person from his ability to enter into a community of persons as well as to fulfill himself in his actions. Wojtyla describes both systems to be "impersonalistic" or "antipersonalistic." Both systems deny the capability of the person to enter into a community. Wojtyla argues that man has the right, even within a community to total freedom of acting. A person still has the freedom to determine himself towards his goals even as he is part of a community. This freedom of action within a community is not to be understood as absolute freedom but rather, as conditioned by the truth and the good.

Individualism says that the common good is a threat to oneself while totalism says that any individual good is a threat to the common good. The concept of person in alienation denies the capability of the person to enter a community where he can experience himself existing and acting together with others towards a common good. The real common good is something that fulfills or creates opportunities to fulfill himself as well as the community. Alienation denies the person of the ability to transcend and fulfill himself in his action because it limits the kinds of relationships he can form. In both systems of individualism and totalism, persons are compromised and are denied of their ability to fulfill themselves in their actions.

In alienation, the person is denied of his natural right and ability to participate. Wojtyla insists that that ability to participate must be cultivated and developed to its fullest maturity. ${ }^{25}$ Alienation restricts the person in the sense that he is not allowed to maximize everything in his ability to fully experience himself as a person. Alienation is un-natural to the person because it goes against his natural ability to associate and relate with other persons. The experience of existing and acting together with others is not only something which should be kept because of nature. It also goes with the necessity for a person to fulfill himself, which always possible on the experience of a community. If a person is denied of those which are naturally his, then it is as if his freedom to determine himself towards his end is taken away from him. Every human being (must) have the right to act, which means "freedom in action," so that the person can fulfill himself in performing the action. ${ }^{26}$ This natural right to be free to determine oneself is based on the reality of actions possessing a personalistic value insofar as they fulfill the person. Man's exercise of freedom in his self-determined actions brings him personal fulfillment. It is important to note that personal fulfillment does not occur with mere performance of actions but can only be found in the performance of good actions hence, good actions fulfill and those which do not fulfill, are called evil. Alienation, which denies the person his ability to fulfill himself is ultimately an evil in society - both to the person and the community of

\footnotetext{
${ }^{25}$ Francisco, op cit., 79.

26 Wojtyla, The Acting Person, 275.
} 
persons. Alienation likewise gives rise to the possibility of even more evils to be inflicted on the person.

Alienation as found in individualism and totalism insists that individual goods and social goods can never be the same. Alienation threatens the person individually and also poses a threat to the community of persons. Alienation is an outright denial of what properly belongs to man - his natural ability to act and fulfill himself as he is existing and acting together with others. One concern to raise here is the fact that such conditions (individualism and totalism) are prevalent in contemporary society. The matter to consider here is the fact that they are problems that are unnoticed or sometimes ignored by society. Some political systems or even societal systems foster the different forms of alienation more than man's capability of forming a community of persons. Alienation is not an event but refers more to a situation or a condition experienced by the person. ${ }^{27}$ In a sense, it is something which is happening and the person is the one experiencing the dangers it poses to himself as well as to others. The root of alienation is profoundly deeper and more personal because it is man who experiences alienation and he is also the one who creates systems which foster alienation. Alienation can happen as a result of many things linked together in a chain. Wojtyla acknowledges these concerns and points to his theory of participation in order to address the problem of alienation.

\section{Wojtyla's Theory of Participation}

Authentic human acting always affirms the personal structure of selfdetermination. An act, insofar as it is brought to be by a person has a personalistic value before a moral value. The personalistic value of the action lies in the fact that the action is performed and in it the person realizes himself according to the structure which is proper to him. ${ }^{28}$ A person exists and acts in a specific manner, along with others. Wojtyla introduces the word Participation to indicate the way in which, in common acting, the person protects the personalistic value of his own acting and participates together in the realization of common action and its outcomes. ${ }^{29}$ Participation points to the ability of the person to exist and act together with others without losing oneself as he moving towards his self-fulfillment.

Participation is to be understood in a twofold manner: it is a property of the person which is expressed in the ability to give a personalistic dimension to his own existence and action while existing and acting together with others and it is also the ability to share in the humanity of others. ${ }^{30}$ Wojtyla says that:

\footnotetext{
27 An event refers to a single moment in an experience. For example, the death of a relative is an event. A condition refers to the mode of being of the person. For example, a person who has lost a huge amount of money is in a miserable condition.

${ }^{28}$ Rocco Buttiglione, Karol Wojtyla The Thought of the Man Who Became Pope John Paul II

(Cambridge: William B. Eerdmans Publishing Company, 1997), 168.

${ }^{29}$ Ibid., 169.

${ }^{30}$ Francisco, op cit., 44.
} 


\section{AGAINST ALIENATION}

... (participation) basically serves to express the property by virtue of which we as persons exist and act together with others, while not ceasing to be ourselves or to fulfill ourselves in action, in our own acts.

And

...the ability to exist and act together with others in such a way that in this existing and acting we remain ourselves and actualize ourselves, which means our own I's. ${ }^{31}$

Participation is a positive relation between persons because it allows the person to experience himself existing and acting together with others. Participation allows the realization of oneself as well as the realization of the community. The ability to participate points to the fact that a person can enter into an interpersonal relationship with other persons and at the same time fulfill himself in his actions. As the antithesis of alienation, participation allows the person to fully experience himself as well as to experience the humanity of other persons. Participation points to the fact that human beings (also) tend toward self-fulfillment and fulfill themselves by existing and acting together with others. ${ }^{32}$ In this sense, the common good and the individual good meet in the person and he seeks them not alone but together with other persons. Participation is not simply the fact of being physically present to one another in a group activity. It is possible that people exist as a group yet pursue their goals individually or in isolation. Participation points to the positive recognition of the common good by the person. It is not something which simply happens but is a result of a person's conscious striving for fulfillment and the realization that he cannot do it alone but must seek it together with others. In participation, a person does not wish for his good alone but also wishes the good of those that are around him. It allows him to open up himself to others and also allows others to share their humanity with him. In a sense, participation allows the person to become more human.

As antithesis to alienation, participation allows the person to maximize his potential inherent in him as a social creature. Participation also opens up a vast array of experiences to the person which will eventually lead him to an even deeper understanding of himself and of others. In participation, a person is called to enter into many different forms of interpersonal relations. It makes it possible for him to experience different roles in their pursuit of a common goal. A good example would be the family - each member is a unique individual whose position in the family is not something which can be replaced by anybody. Their difference also accounts for the very dynamic relationship that occurs within the family. Every member has a task to fulfill which only

\footnotetext{
31 Wojtyla, Person and Community Selected Essays, 200.

32 Ibid., 254.
} 
he/she can do. All of these tasks contribute to the growth and development not only of its members but also of the group (the family) as a whole. As persons grow, the community grows in the process and vice versa. Participation ensures that persons fulfill themselves as they work towards a common good. This is so, because the person has the natural right to perform actions, communal or otherwise, and to be fulfilled in them. ${ }^{33}$

The common good does not refer to one single and fixed object but rather refers to a good, which is shared by two or more persons. The common good, by definition is something recognized by persons as a real good and thus work together with others in pursuit of this good. Different situations and different communities call for different common goods but what remains the same is the fact that this common good cannot be just anything out there but must always have reference to the truth for it to be a real common good worthy of pursuit by persons.

\section{Authentic and Inauthentic Attitudes of Participation}

Participation takes different forms. Wojtyla differentiates them as authentic and inauthentic attitudes. The authentic attitudes of participation are solidarity and opposition. Solidarity means a constant readiness to accept and to realize one's share in the community because of one's membership within that particular community. ${ }^{34}$ Solidarity expresses the unity of the parts (members) in their pursuit of the common good. Persons who are linked together in the attitude of solidarity realize the fact that they are members of a group and that they have to work together to achieve the good of the group. This does not mean that the individual good is opposed to the good of the group. But instead, it is a recognition of the true value of the common good which is the reason why the person takes it as his task to participate in its achievement. Solidarity involves a complementariness of the members of a community all working together for a common good. Opposition is not the opposite of solidarity but is another mode of it. Opposition means to oppose something for the sake of the common good. Opposition is when, in the name of genuine participation, one opposes what is, or what one judges to be, contrary to the common good. ${ }^{35}$ Admittedly, there are many goods that are presented as apparently common. The attitude of opposition is borne out of the recognition that there is a need to defy from the apparent common good for the sake of the real common good. Opposition does not mean the denial or the withdrawal of the person in pursuit of the common good but is a result of their recognition of the common good. A typical case here would be the opposition against laws that are harmful to the humanity of persons (abortion, divorce, prostitution, etc). In both cases, the attitudes of solidarity and opposition are ways by which the person, in his recognition and willingness to

\footnotetext{
33 Simpson, op cit., 39.

34 Wojtyla, The Acting Person, 285.

35 Simpson, op cit., 41.
} 


\section{AGAINST ALIENATION}

participate, contribute to the promotion of the common good. He takes it as his task to ensure that he does his part in the achievement of the common good.

The inauthentic attitudes of participation are conformism and noninvolvement. Conformism denotes a tendency to comply with the accepted custom and to resemble others, a tendency that is in itself neutral, in many respects positive and constructive or even creative. 36 While conformism may contribute to the achievement of the common good, the main problem in conformism is the fact that persons do not really appreciate the value of their work. In an ordinary way of putting it, they are just "going with the flow." People may be conforming to an idea which does not really agree with the common good. There are various reasons why people conform but all of them point to the fact that there is really no unity but only uniformity. People adapt themselves to the demands of the community in a superficial way for purposes of gaining some immediate advantages or avoiding opposition. Thus, the conformist is one who submits himself to pressures of others and, at the same time, withdraws from the community. ${ }^{37}$ The other inauthentic attitude of participation is non-involvement or avoidance. It is characterized by a disregard for those appearances of concern for the common good which also characterizes conformism. It is nothing but a withdrawal but it lacks the active concern of participation; moreoever, it characterizes man's absence from the community. ${ }^{38}$ Noninvolvement is also characterized by indifference to the common good. It is a substitute to the authentic attitudes because they do not find value in both solidarity and opposition. Noninvolvement is a way by which a person abstains from participating in the community. On the surface, it does appear to be a sign of protest but, it is just an escape of the person from his role in the community. This inauthentic attitude is characterized mainly by a disinterested attitude or a sign of distrust to the community. Both inauthentic attitudes are characterized by the absence of the person's active participation in the community. The difference lies in the person's convictions, motives and reasons for performing such activities. Both inauthentic attitudes deny him of his capability to participate in the achievement and the benefits of the common good. The inauthentic attitudes of participation stand in the way in the formation of an interpersonal community. What results is a very fragmented society and people become apathetic and disinterested in matters other than their own.

Participation leads to the establishment of harmony between persons. A community of persons participating in the pursuit of the common good contributes to the growth and development of persons. A community built on the conscious participation of persons for the common good is a community that brings persons closer to their fulfillment. Participation allows every person to experience one another as a neighbor and a member of the

\footnotetext{
36 Wojtyla, The Acting Person, 289.

37 Francisco, op cit., 71.

38 Wojtyla, The Acting Person, 290.
} 
community. Participation opens up the fact that a person is not only capable of participating in the community of existing and acting persons but also of his capability to participate in the humanity of others. This points to the ability of the person to experience his neighbor as another $I$. The fullness of the capability to participate in the humanity of others finds expression in the commandment to love.

The commandment to love entails a juxtaposition of the self and the neighbor as expressed in "love thy neighbor as thyself." When the neighborship is the basis of interpersonal relations, it enables a person to go beyond the fundamental relationship of being member of a community. The neighborrelation does not only help a community to be formed but it also enables a community to be a community of persons. A community of persons must be founded on love - the recognition and affirmation of the value of the person. It is when a person truly loves his neighbor can he fully participate in the humanity of others and at the same time fulfill himself in the process. Every person is always a member of a community and at the same time, every person is a neighbor. Through love, man is able to transcend himself and enter into the humanity of his neighbor. It is in through love that the recognition of the person becomes the very basis and norm governing every authentic community.

Participation is not just a property of the person but is also a task of the person to fulfill. Persons are called to participate not only in the aspect of acting with other persons but are called to participate in the humanity of their neighbors. Participation allows the person to transcend his limits to reach out to others and fulfill himself. To love another person is to affirm the other as a subject also capable of participating in the humanity of others. Participation points to the person's ability to experience himself and others as persons. Participation also affirms the person's freedom to determine himself in his actions. It recognizes the fact that the person tends towards the good, chooses it freely and willingly. There can be no possibility of affirmation and fulfillment if the person were not free to pursue his own ends.

Wojtyla's presentation of participation is not a full-blown analysis nor does he create a political philosophy out of it. What he was aiming for was an outline or a guide by which political systems could follow so as to prevent any dangers and threats to the human person. Participation sustains and enriches the interpersonal relationship between persons. What makes participation possible is the common humanity shared by all men, and its recognition inevitably leads to the formation of a community where everyone is a neighbor to another.

\section{Conclusion}

Alienation manifests itself in different ways. Alienation points to a situation where a person is denied of the possibility of experiencing a person as another subject. The main thing to be concerned about in alienation is its denial of the person his capability of participating in the humanity of others. 


\section{AGAINST ALIENATION}

Alienation does not allow persons to experience the fullness of their humanity and the humanity of others. When persons are alienated, they are denied of their ability to fulfill themselves in their actions. In a certain sense of saying, their action loses meaning and significance because the person cannot experience the fulfillment proper to him in the performance of actions. It also becomes impossible for him to enter into an interpersonal relationship with others. What might just happen is a person-to-object relationship as opposed to a person-to-person relationship. Participation as the antidote to alienation affirms the basic experience of the person who is existing and acting together with others. Participation opens up the wealth of experience of a person towards his self-fulfillment. Participation allows the person to enrich himself as he is working to fulfill the common good and at the same also allows him to fulfill himself. The culmination of participation is found in the commandment to love which points to the fact that person do not simply participate in existing and acting but ultimately share in the humanity of other persons. Participation allows a person to experience himself as well as other persons as other I's who are also concrete, existing and acting. Participation recognizes the specific characteristics of persons and also allows them to enrich themselves further.

The focus on the human person borne out of an honest and sincere interest in philosophy will inevitably start dealing with concerns as such. In the contemporary world, there are still many conditions which prevent a person or somewhat make it more difficult for a person to fulfill himself. The inability to experience one's fulfillment ultimately makes life miserable for the person. The recognition of the fact that the other person is a neighbor whom we should love should be the prevalent mode of relating with others. In a community of persons founded on love, a person opens himself up to others and eventually fulfills himself in the process.

The fight against alienation is far from over. As much as Wojtyla's works were reflective of the condition (specifically in his homeland) of the world during his time, many of those things are still present even today. The difficult part is pinpointing the conditions and the situations which actually allow alienation to occur.

Perhaps the challenge left by Karol Wojtyla to his readers is to really live the philosophy of the human person - live with the concern, respect and love for the humanity of other persons. It is only in actions that have reference to the truth and the good can a person fully find the meaning of his existence and ultimately direct his actions towards his fulfillment. There is a

saying that goes "no man is an island" - to be understood in a deeper sense, it is important to recognize the fact that it is good to establish harmony between persons. It is good to be part of a community of persons. It is good to share and participate in the humanity of other persons for these are things which ultimately contribute to the fulfillment of the person as well as his community. Only in a community founded on love can a person really experience the richness of being a person. It is a task of every single person and it will never happen unless persons recognize its importance and goodness. Karol Wojtyla 
reveals to us a great task to work on but is very much deserving of the efforts of persons.

As Pope John Paul II, in St. Peter's Square, on October 22, 1978 -one of the first words he addressed to the world was, "Be not afraid." His message was clear - that man need not be afraid for he has been redeemed by God. ${ }^{39}$ In the light of his philosophy, it can be said that he is calling upon the people not to live in fear but rather, to boldly seek the truth and pursue the good of man. This entails a reflection on oneself, and recognition of a need to make positive changes to the world. As Pope, his message reached far and wide across the whole world.

Department of Philosophy, University of Asia and the Pacific, Philippines

\section{References}

Altez, Fleurdeliz, "The Dignity of the Responsible Agent: Thomism and Phenomenology in the Personalism of John Paul II," in Ad Veritatem, vol. 6 no. 2 (2007), 595-612.

Aquino, Ranhilio, "Karol Wojtyla's Philosophy of The Acting Person," in The Thomasian Philosopher, vol. 26 (2005), 28-37.

Buttiglione, Rocco, Karol Wojtyla The Thought of the Man Who Became Pope John Paul II, trans. Paolo Guietti and Francesca Murphy (Cambridge: William B. Eerdmans Publishing Company, 1997).

De Torre, Joseph, Christian Philosophy (Manila: Sinag-Tala Publishers, 1980).

Francisco, Rolyn B., Karol Wojtyla's Theory of Participation (Makati: St. Paul's, 1995).

Montalbo, Melchor, "Karol Wojtyla's Philosophy of The Human Person," in The Thomasian Philosopher, vol. 26 (2005), 3-27.

Pasricha, Josephine, "In Homage to John Paul II 'the Great' Postmodern Pope," in Karunungan, vol. 23 (2006), 151-172.

Pope John Paul II, Crossing the Threshold of Hope (New York: Alfred A. Knopf, 1994).

Simpson, Peter, On Karol Wojtyla (Australia: Wadsworth, 2001).

Wojtyla, Karol, Love and Responsibility, trans. by H.T. Willets (San Francisco: Ignatius Press, 1993).

Person and Community Selected Essays, trans. by Theresa Sandok

(New York: Peter Lang, 1993).

, The Acting Person, trans. by Andrej Potocki (Dordrecht: D. Reidel Publishing Company, 1979).

${ }^{39} \mathrm{Man}$ is an Imago Dei- one who was created in the image and likeness of God. Thus, man also shares in some ways in God's providence. Man occupies a special place among God's creatures. This special place was affirmed when Jesus Christ died on the cross for the sins of man. 